GSA 2001 BOSTON Abstract

MOL. 20010913.0193

\title{
VAPOR-PHASE GARNET AT YUCCA MOUNTAIN, NEVADA: GEOCHEMISTRY AND OXYGEN-ISOTOPE THERMOMETRY
}

MOSCATI, Richard J., rmoscati@usgs.gov; JOHNSON, Craig A., cjohnso@usgs.gov; and WHELAN, Joseph F., jfwhelan@usgs.gov; U.S. Geological Survey, MS 963, Box 25046, Denver Federal Center, Denver, CO 80225

Key Words: garnet, Yucca Mountain, vapor-phase, oxygen-isotope, tridymite

\section{ABSTRACT}

About 20 vapor-phase garnets were studied in two samples of the Topopah Spring Tuff from Yucca Mountain, in southern Nevada. The Miocene-age Topopah Spring Tuff is a 350-m-thick, devitrified, moderately to densely welded ash flow that is compositionally zoned from high-silica rhyolite to quartz latite. During cooling of the tuff, escaping vapor produced lithophysae (former gas cavities) lined with an assemblage of tridymite, cristobalite, alkali feldspar, and locally, hematite and/or garnet. Vapor-phase topaz and economic deposits (such as porphyry molybdenumtungsten) commonly associated with topaz-bearing rhyolites (characteristically enriched in fluorine) were not found in the Topopah Spring Tuff at Yucca Mountain. The garnets are not primary igneous phenocrysts, but rather crystals that grew from a fluorine-poor magma-derived vapor trapped during emplacement of the tuff. The garnets are euhedral, vitreous, reddish brown, trapezohedral, as large as $2 \mathrm{~mm}$ in diameter, and fractured. The garnets also contain inclusions of tridymite. Electronmicroprobe analyses of the garnets reveal that they are almandine-spessartine ( 48.0 and $47.9 \mathrm{~mol}$ percent, respectively), have an average chemical formula of $\left(\mathrm{Fe}_{1.46}, \mathrm{Mn}_{1.45}\right.$, 
$\left.\mathrm{Mg}_{0.03}, \mathrm{Ca}_{0.10}\right)\left(\mathrm{Al}_{1.93}, \mathrm{Ti}_{0.02}\right) \mathrm{Si}_{3.01} \mathrm{O}_{12}$, and are homogeneous in $\mathrm{Fe}$ and $\mathrm{Mn}$ concentrations from core to rim. Composited garnets from each sample site have $\delta^{18} \mathrm{O}$ values of 7.2 and $7.4 \%$. The coexisting tridymite, however, has $\delta^{18} \mathrm{O}$ values of 17.4 and $17.6 \%$, values indicative of reaction with later, low-temperature water. Unaltered tridymite from higher in the stratigraphic section has a $\delta^{18} \mathrm{O}$ of $11.1 \%$ which, when coupled with the garnet $\delta^{18} \mathrm{O}$ values in a quartz-garnet fractionation equation, indicates vapor-phase crystallization at temperatures of almost $600^{\circ} \mathrm{C}$. This high-temperature mineralization, formed during cooling of the tuffs, is distinct from the later and commonly recognized low-temperature stage (generally $50-70^{\circ} \mathrm{C}$ ) of calcite, quartz, and opal secondary mineralization, formed from percolating meteoric water, that locally coats fracture footwalls and lithophysal floors. 